\title{
PROSES PENYELESAIAN SENGKETA DI LEMBAGA ALTERNATIF PENYELESAIAN SENGKETA PERBANKAN INDONESIA (LAPSPI)
}

\author{
Yosua Gabriel Pradipta \\ E-mail: yosuagabriel16@gmail.com \\ Mahasiswa Fakultas Hukum Universitas Sebelas Maret Surakarta \\ Dona Budi Kharisma \\ E-mail: donabudikharisma@gmail.com \\ Dosen Fakultas Hukum Universitas Sebelas Maret Surakarta
}

\begin{abstract}
This articels discusses how to discuss the process of dispute resolution at the Indonesian Institute for Alternative Banking Dispute Resolution (LAPSPI). In this study, the author uses empirical legal research methods. This research is descriptive. By referring to the invitation, the primary legal material used in this study is the legislation and secondary legal materials used consisting of legal books and relevant legal journals. The technique of answering legal material carried out by the author in this legal discussion is in the form of library studies, interviews or interviews. This study uses a qualitative method. Based on the results of the research and discussion, it was concluded that LAPSPI had 3 (three) services that could be used to complement banks that is mediation, adjudication, and arbitration.
\end{abstract}

Keywords: Banking disputes; LAPSPI; Banking Dispute Settlement.

\begin{abstract}
Abstrak
Artikel ini bertujuan unutk mengetahui bagaimana proses penyelesaian sengketa di Lembaga Alternatif Penyelesaian Sengketa Perbankan Indonesia (LAPSPI). Pada penelitian ini, penulis menggunakan metode penelitian hukum empiris. Penelitian ini bersifat deskriptif. Dengan pendekatan perundang-undangan, bahan hukum primer yang digunakan dalam penelitian ini berupa peraturan perundang-undangan serta bahan hukum sekunder yang digunakan berupa buku-buku hukum dan jurnal hukum yang relevan. Teknik pengumpulan bahan hukum yang dilakukan oleh penulis di dalam penulisan hukum ini berupa studi kepustakaan, wawancara atau interview. Teknik analisa bahan hukum dalam penelitian ini yaitu menggunakan metode kualitatif. Berdasarkan hasil penelitian dan pembahasan dihasilkan kesimpulan yaitu LAPSPI memiliki 3 (tiga) layanan yang dapat digunakan dalam menyelesaikan sengketa perbankan yaitu mediasi, ajudikasi, dan arbitrase.
\end{abstract}

Kata kunci : Sengketa perbankan; LAPSPI; Penyelesaian Sengketa Perbankan.

\section{A. Pendahuluan}

Alternatif penyelesaian sengketa menurut George Appelbay dalam tulisannya $A n$ overview of alternatif dispute resolution berpendapat bahwa $A D R$ pertama-tama merupakan suatu eksperimen untuk mencari model-model baru dalam penyelesaian sengketa, penerapan baru terhadap metode-metode lama, forum-forum baru terhadap penyelesaian sengketa, penekanan yang berbeda dalam pendidikan hukum (Sophar Maru Hutagalung,2014) 
Adanya potensi sengketa tersebut perlu disikapi dengan memberikan fasilitas perlindungan yang baik terhadap konsumen pada sektor jasa keuangan. Pemberlakuan Undang-Undang Nomor 21 Tahun 2011 tentang Otoritas Jasa Keuangan (UU OJK) membawa harapan dan kepastian bahwa kepentingan konsumen dapat terlindungi dengan baik dengan terselenggaranya kegiatan di sektor jasa keuangan yang teratur, adil, transparan, dan akuntabel serta mampu mewujudkan sistem keuangan yang tumbuh secara berkelanjutan dan stabil, dan mampu melindungi kepentingan konsumen dan masyarakat (Agus Suwandono dan Deviana Yuanitassari, 2016). Berdasarkan isi UU OJK yaitu Undang-Undang Nomor 21 Tahun 2011 tentang Otoritas Jasa Keuangan, Pembentukan OJK adalah untuk melindungi kepentingan konsumen dan masyarakat. Pembentukan OJK sendiri diharapkan dapat melindungi kepentingan konsumen dan masyarakat yang menggunakan/memanfaatkan pelayanan lembaga jasa keuangan. Untuk mencapai tujuan tersebut UU OJK memberikan kewenangan edukasi, pelayanan pengaduan, sampai dengan pembelaan hukum terhadap konsumen yang dirugikan oleh lembaga jasa keuangan terhadap OJK. Sebelum terbentuknya OJK, tugas dan wewenang di sektor jasa keuangan dipegang oleh beberapa lembaga tertentu yang berbedabeda untuk setiap jenis jasa keuangan. OJK sendiri berfungsi untuk menyelenggarakan sistem pengaturan dan pengawasan yang terintegrasi terhadap keseluruhan kegiatan di sektor jasa keuangan (Ema Rahmawati dan Rai Mantili, 2016). Dalam rangka melakukan upaya perlindungan terhadap konsumen dan pelaku usaha di sektor jasa keuangan, maka dikeluarkanlah peraturan pertama OJK yaitu Peraturan Otoritas Jasa Keuangan Nomor 1/ POJK.07/2013 tentang Perlindungan Konsumen Sektor Jasa Keuangan (POJK Perlindungan Konsumen). Berdasarkan Pasal 2 POJK Perlindungan Konsumen. Perlindungan konsumen sektor jasa keuangan wajib menerapkan prinsip transparansi, perlakuannya yang adil, keandalan, kerahasiaan dan keamanan data/informasi konsumen, dan penanganan pengaduan serta penyelesaian sengketa konsumen secara sederhana, cepat, dan biaya terjangkau (Abd. Aziz Billah,2018)

Setelah itu OJK menerbitkan Peraturan Otoritas Jasa Keuangan (POJK) nomor 1/ POJK.07/2014 tentang Lembaga Alternatif Penyelesaian Sengketa di Sektor Jasa Keuangan, lembaga alternatif penyelsaian sengketa yang khusus menangani perbankan adalah Lembaga Alternatif Penyelesaian Sengketa Perbankan Indonesia (LAPSPI).Dengan didirikannya LAPSPI diharapkan dapat memberi pilihan penyelesaian sengketa perbankan dan tentunya dapat menciptakan keadilan bagi nasabah maupun bank. Berdasarkan uraian diatas artikel ini membahas mengenai Proses Penyelesaian Sengketa Di Lembaga Alternatif Penyelesaian Sengketa Perbankan Indonesia (LAPSPI).

\section{B. Metodologi Penelitian}

Penelitian ini merupakan penelitian empiris yang bersifat deskriptif. Pendekatan yang digunakan adalah pendekatan kasus. Sumber bahan hukum yang digunakan adalah bahan hukum primer dan sekunder. Teknik pengumpulan data yang digunakan adalah studi kepustakaan dan wawancara, dengan teknik analisis yang digunakan merupakan metode deduktif.

\section{Hasil Penelitian dan Pembahasan}

Berdasarkan Pasal 4 POJK Nomor 1/POJK.07/2014 tentang Lembaga Alternatif Penyelesaian Sengketa Lembaga Alternatif Sengketa wajib memiliki setidaknya 3 (tiga) 
layanan penyelesaian sengketa yaitu mediasi, ajudikasi, dan arbitrase. LAPSPI yang dalam hal ini termasuk sebagai salah satu Lembaga Alternatif Penyelesaian Sengketa yang termasuk kedalam daftar LAPS yang ditetapkan OJK berdasarkan Keputusan Nomer KEP-6/D.07/2016 Tentang Daftar Lembaga Alternatif Penyelesaian Sengketa di Sektor Jasa Keuangan sehingga LAPSPI juga wajib memiliki 3 (tiga) layanan tersebut. Berdasarkan wawancara yang saya lakukan, bank maupun nasabah ketika mengalami sengketa dan tidak dapat menyelesaikannya secara intenal dan memiilih LAPSPI sebagai tempat penyelesaian sengketa maka mereka dapat memilih salah satu layanan tersebut .

Bagan Alur Penyelesaian sengketa di LAPSPI

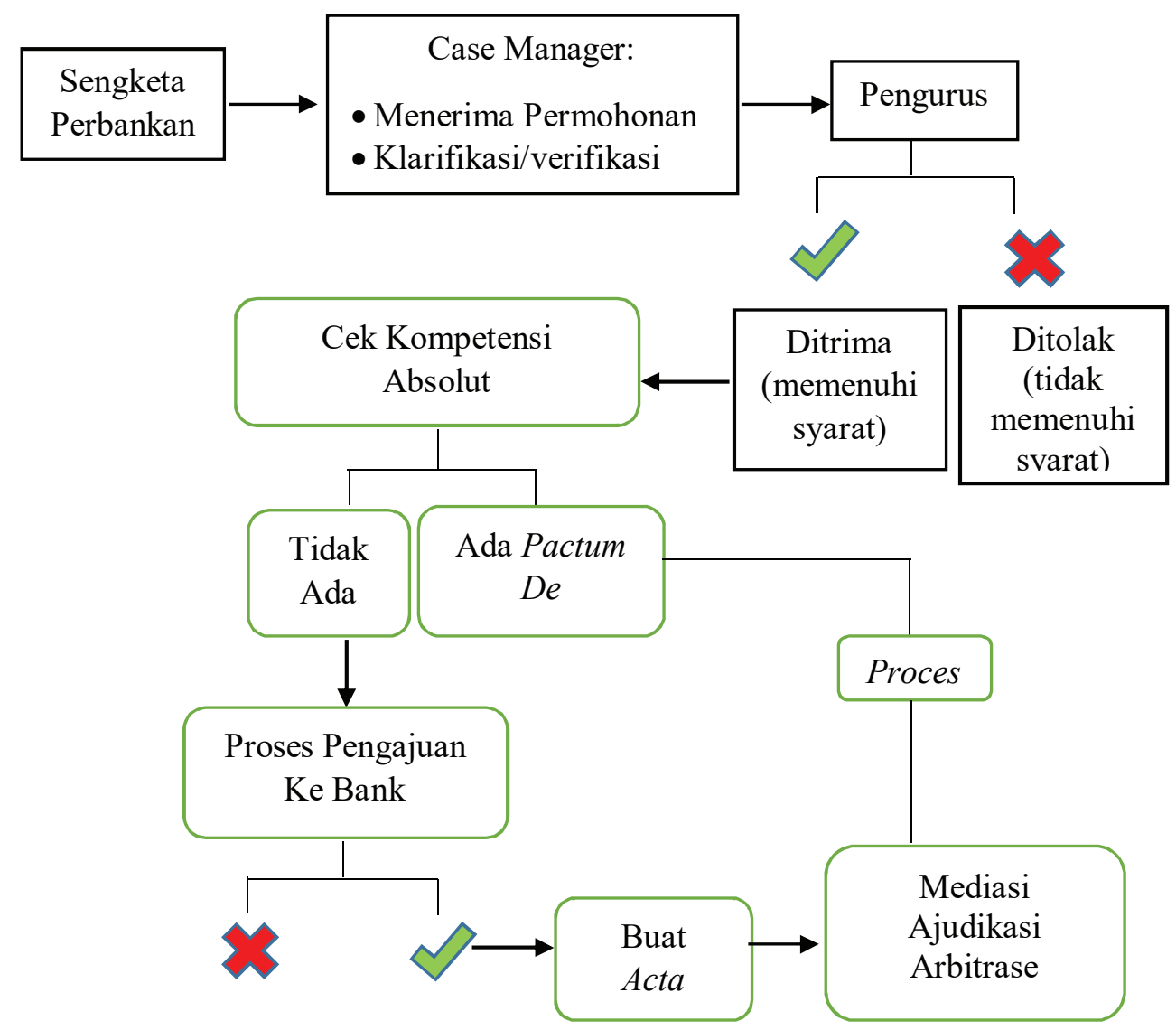

Bagan diatas merupakan alur penanganan kasus sengketa diLAPSPI beriktut adalah penjelasan bagan alur penanganan kasusu sengketa diLAPSPI:

1. Pertama, terjadi sengketa dibidang perbankan yang menyebabkan kerugian yang dapat diukur dengan materi.

2. Kedua, case manager menerima permohonan penyelesaian sengketa dan menganalisa apakah sengketa yang masuk merupakan sengketa dibidang perbankan atau terkait dengan perbankan, lalu memeriksa apakah sengketa tersebut lebih dahulu telah diselesaikan secara internal dengan perbankan (internal dispute resolution) dan terakhir memeriksa apakah sengketa tersebut belum pernah diperiksa atau diputuskan oleh pengadilan negeri.

3. Ketiga, pengurus akan menentukan apakah sengketa tersebut dapat diselesaikan melalaui salah satu layanan LAPSPI. Sengketa tersebut dapat ditolak jika:

a. Tidak sesuai dengan definisi sengketa perbankan

b. Sudah diputus oleh pengadilan/lembaga lain 
c. Perbutan melawan hukum (PMH)

d. Ditolak oleh pemohon

4. Keempat, jika sengketa tersebut telah memenuhi syarat dan telah diterima oleh pengurus LAPSPI selanjutnya yang dilakukan adalah mengecek kompetensi absolut sengketa tersebut apakah ada perjanjian terikat antara bank dengan nasabah untuk menyelesaikan sengketa di lembaga tertentu.

5. Kelima, setelah dilakukan pengecekan mengenai perjanjian penyelesaian sengketa jika para pihak sudah menunjuk LAPSPI sebagai tempat penyelesaian sengketa maka selanjutnya para pihak segera memulai proses penyelesaian sengket berdasarkan layanan yang sudah di perjanjikan baik layanan mediasi, ajudikasi, maupun ajudikasi. Namun jika saat pengecekan kompetensi absolut tidak ditemukan adanya perjanjian mengenai penyelesaian sengketa maka selanjutnya LAPSPI menindak lanjuti laporan pelapor untuk mengajukan kepada bank apakah bank tersebut mau untuk menyelesaikan sengketa di LAPSPI atau tidak

6. Keenam, Jika bank menyetujui untuk menyelesaiakan sengketa di LAPSPI maka para pihak diarahkan untuk membuat acta compromise yaoitu perjanjian untuk menyelesaikan sengketa melalui mediasi, ajudikasi, maupun arbitrase setelah terjadinya sengketa.

Setelah proses diatas maka para pihak akan menyelesaikan perkara sesuai layanan yang telah mereka sepakati. Mediasi, ajudikasi dan arbitrase memiliki alur penyelesaian yang sama seperti yang telah dijelaskan diatas. Perbedaannya baru lah pada tahap proses penyelesaiannya yang akan dijelaskan dibawah ini:

7. Mediasi

Mediasi menurut Gary Goodpaster, mengemukakan mediasi adalah proses negosiasi pemecahan masalah dimana pihak luar yang tidak memihak (impartial) dan netral bekerja dengan pihak yang untuk membantu mereka memporoleh kesepakatan perjanjian dengan memuaskan. Berbeda dengan hakim atau arbiter, mediator tidak mempunyai wewenang untuk memutuskan sengketa antara pihak (Riska Fitriani, 2017)

LAPSPI mempunyai dua (2) layanan didalam layanan mediasi yang berbeda dengan layanan ajudikadi dan arbitrase yang hanya memiliki satu (1) jenis layanan saja yaitu:a. Layanan Probono yaitu layanan mediasi secara cuma - cuma yang diberikan LAPSPI terhadap para pihak untuk sengketa dengan tuntutan ganti rugi maksimal sebesar Rp. 500.000.000 (lima ratus juta rupiah). Dalam layanan ini para pihak tidak bisa memilih mediator, akan tetapi pengurus LAPSPI yang menunjuk 1 (satu) orang mediator tetap LAPSPI untuk menangani penyelesaian sengketa para pihak. b. Layanan Komersial yaitu layanan yang diberikan LAPSPI terhadap sengketa dengan tuntutan ganti rugi diatas Rp. 500.000.000 (lima ratus juta rupiah) dalam layanan ini para pihak juga berhak memilih satu (1) atau paling banyak dua (2) orang mediator yang tercatat didalam daftar mediator tetap LAPSPI

Para pihak dalam menghadiri pertemuan perundingan mediasi yang diselenggarakan oleh mediator harus menghadiri pertemuan perundingan tersebut dan tidak boleh hanya diwakilkan hanya diwakilkan oleh kuasa hukumnya saja. Jika diperlukan oleh mediator bahkan kehadiran kuasa hukum dapat dibatasi oleh mediator untuk kelancaran perundingan. Jika suatu pihak merupakan badan hukum, maka harus diwakilkan oleh pengurus atau pegawainya yang berwenang dan sah atau berdasarkan surat kuasa khusus yang isinya menyatakan kapasitas perwakilan badan hukum tersebut, yaitu seperti: 
1. Mewakili badan hukum

2. Mengambil keputusan untuk dan atas nama badan hukum

3. Membuat perdamaian untuk dan atas nama badan hukum.

Selama proses mediasi belum mencapai kesepakatan perdamaian maka salah satu pihak dapat menyatakan mundur dari proses mediasi kepada mediator, dengan tembusan kepada pihak lainnya dan pengurus. Dengan syarat adanya alasan dan bukti yang kuat bahwa pihak lain menunjukan itikad tidak baik dalam menjalani proses mediasi.

Setelah selesinya proses perundingan mediasi akan menghasilkan tiga hasil yang berbeda yaitu mediasi mencapai kesepakatan, kesepakatan perdamaian sebagian, dan mediasi tidak mencapai perdamaian,

Berikut tahap proses mediasi:

1. Proses Pra Mediasi

a. Para pihak atau salah satu pihak yang bersengketa mendaftarkan kasusnya ke LAPSPI

b. Para pihak bersama-sama menunjuk mediator (untuk layanan komersil) yang sesuai dengan sifat perkaranya

c. Mediator yang ditunjuk mengadakan pertemuan dengan seluruh pihak membahas peran mediator dan prosedur

2. Proses Mediasi - Negoisasi

a. Mediator mengadakan pertemuan terpisah dengan para pihak dalam mengumpulkan informasi awal

b. Mediator mengadakan pertemuan dengan semua pihak untuk bersama-sama mendefinisikan permasalahan, kepentingan dan kebutuhan para pihak yang bersengketa

c. Mediator membantu para pihak untuk mengembangkan alternatif penyelesaian atas permasalahan, kepentingan dan kebutuhan yang telah didefinisikan

d. Para pihak bernegosiasi untuk mencaai kesepakatan atas alternatif penyelesaian yang dipandu oleh mediator

3. Proses Akhir Mediasi

a. Apabila Tercapai suatu kesepakatan, para pihak akan menandatangani sebuah dokumen penyelesaian yang selanjutnya akan di proses ke dalam bentuk perjanjian yang mengikat

b. Bila tidak tercapai suatu kesepakatan, para pihak dapat mengakhiri mediasi dengan mengajukan pengunduran diri dari proses mediasi.

\section{Ajudikasi}

Merupakan cara penyelesaian sengketa diluar arbitrase dan peradilan umum yang dilakukan oleh ajudikator untuk menghasilkan suatu putusan yang dapat diterima oleh pemohon yang tidak berhasil dalam mencapai kesepakatan mediasi di Lembaga Alternatif Penyelesaian Sengketa Perbankan Indonesia (LAPSPI. Layanan ajudikasi hanya diberikan kepada nasabah dengan tututan ganti rugi sampai Rp500.000.000 (lima ratus juta rupiah) yang tidak mencapai kesepakatan dalam layanan mediasi probono dan para pihak dalam waktu maksimal 5 hari sejak sengketa tersebut diterima LAPSPI para 
pihak haruslah terlebih dahulu membuat dokumen perjanjian mediasi, apabilla dalam waktu yang ditentukan para pihak belum juga membuatnya maka permohonan ajudikasi diangap belum pernah dilakukan.

Alur proses Ajudikasi:

1. Proses Pra ajudikasi
a. Tidak terjadinya kesepakatan pada proses mediasi
b. Para pihak bersama-sama menunjuk ajudikator yang sesuai dengan sifat perkaranya
c. Ajudikator yang ditunjuk mengadakan pertemuan dengan seluruh pihak mem- bahas peran mediator dan prosedur

2. Proses ajudikasi - Negoisasi
a. Ajudikator mengadakan pertemuan terpisah dengan para pihak dalam meng- umpulkan informasi awal
b. Ajudikator mengadakan pertemuan dengan semua pihak untuk bersama-sama mendefinisikan permasalahan, kepentingan dan kebutuhan para pihak yang bersengketa
c. Ajudikator membantu para pihak untuk mengembangkan alternatif penyelesaian atas permasalahan, kepentingan dan kebutuhan yang telah didefinisikan
d. Para pihak bernegosiasi untuk mencapai kesepakatan atas alternatif penyelesa- ian yang dipandu oleh ajudikator

3. Proses Akhir ajudikasi
a. Apabila pemohon setuju mengenai hasil keputusan ajudikasi maka keputusan tersebut otimatis mengikat kedua belah pihak yang bersengketa. Namun jika yang tidak setuju adalah termohon maka putusan tersebut tetaplah mengikat keduabelah pihak
b. Bila pemohon tidak setuju dengan hasil keputusan ajudikasi maka keputusan tersebut dapat dibatalkan.

\section{Arbitrase}

Merupakan cara penyelesaian sengketa perdata bidang perbankan dan yang terkait bidang pebankan diluar peradilan umumyang diselenggarakan oleh LAPSPI dengan menggunakan peraturan dan prosedur arbitrase LAPSPI yang didassarkan pada perjanjian arbitrase, yang dibuat secara tertulis oleh para pihak yang bersengketa. Arbitrase LAPSPI dilakukan oleh arbiter yang telah diangkat dan dimasukan kedalam daftar arbiter tetap LAPSPI. kualifikasi tertentu yang dibutuhkan untuk memeriksa perkara yang bersangkutan.

Layanan Arbitrase di LAPSPI khusus diberikan untuk sengketa dengan jumlah tuntutan ganti rugi senilai diatas Rp500.000.000 (lima Ratus juta rupiah). Jumlah arbiter dalam tiap penyelesaian sengketa arbitrase berbeda namun jumlahnya haruslah ganjil.

Proses pemeriksaan arbitrase paling lama adalah 180 hari yang dihitung sejak pengangkatan arbiter tunggal/majelis arbitrase. Namun jangka waktu tersebut tidak termasuk waktu yang terpakai dalam rangka pemeriksaan dan pelaksanaan putusan 
provisionil ataupun putusan sela lainnya serta dalam rangka menyusun putusan arbitrase. Alur proses arbitrase:

a) Persetujuan arbitrase harus dimuat dalam suatu dokumen (tertulis) suatu sendketa yang akan terjadi pada mereka untuk diselesaikan melalui Arbitrase LAPSPI

b) Jumlah arbiter harus ganjil. Penunjukkan dua arbiter dilakukan oleh para pihak yang memiliki wewenang untuk memilih dan menunjuk arbiter yang ketiga yang nantinya bertindak sebagai ketua majelis arbitrase. Arbiter yang ditunjuk dan diangkat tersebut dapat menerima atau menolak penunjukkan atau pengangkatan tersebut. Dalam hal arbiter telah menyatakan menerima penunjukan atau pengangkatannya, ia tidak dapat menarik diri, kecuali atas persetujuan para pihak.

c) Sebelum pemohon mengajukan pendaftaran permohonan arbitrase kepada LAPSPI, pemohon terlebih dahulu memberitahukan kepada termohon dengan tembusan kepada pengurus melalui surat tercatat, telegram, faksimili, email, atau dengan surat yang dikirimkan melalui kurir bahwa syarat arbitrase yang diadakan para pihak sudah berlaku namun jika perjanjian arbitrase telah dibuat sebelum munculnya sengketa maka hal tersebut tidak diperlukan lagi.

d) Pengajuan permohonan arbitrase harus dilakukan secara tertulis, dengan cara menyampaikan surat tuntutan kepada arbiter atau majelis arbitrase yang memuat sekurang-kurangnya nama lengkap dan tempat tinggal atau kedudukan para pihak, uraian singkat tentang sengketa yang disertai dengan lampiran bukti-bukti, dan isi tuntutan yang jelas.

e) Kemudian, salinan surat tuntutan dari pemohon tersebut disampaikan kepada termohon dengan disertai perintah bahwa termohon harus menanggapi dan memberikan jawabannya secara tertulis dalam waktu paling lama 14 hari saja diterimanya salinan tuntutan tersebut oleh termohon, yang selanjutnya diteruskan kepada pemohon. Bersamaan dengan itu, arbiter atau ketua majelis arbitrase akan memerintahkan kepada para pihak atau kuasa mereka menghadap di muka siding arbitrase yang ditetapkan paling lama 14 hari terhitung mulai dari dikeluarkannya perintah itu.

f) Penyelesaian berdasarkan kesepakatan para pihak, yang dilakukan menurut peraturan dan prosedur LAPSPI.

g) Pemeriksaan sengketa arbitrase harus dilakukan secara tertulis, kecuali jika disetujui para pihak atau dianggap perlu oleh arbiter atau oleh majelis arbitrase dilakukan secara tertutup.

h) Dalam dalam setiap pemeiksaan arbitrase arbiter atau majelis arbitrase terlebih dulu mengusahakan perdamaian di antara para pihak yang bersengketa. Apabila usaha perdamaian tercapai, arbiter atau majelis arbitrase menuangkan kesepakatan perdamaian tersebut yang final dan mengikat para pihak dan memerintahkannya untuk memenuhi ketentuan perdamaian tersebut. Sebaliknya, apabila usaha perdamaian tidak berhasil, pemerintah terhadap pokok sengketa akan dilanjutkan.

i) Pemeriksaan atas sengketa harus diselesaikan dalam waktu paling lama 180 hari saja sejak arbiter atau majelis arbitrase terbentuk. Jangka waktu itu dapat diperpanjang dengan persetujuan para pihak dan hal ini diperlukan.

j) Atas perintah arbiter atau majelis arbitrase atau atas permintaan para pihak dapat dipanggil seorang saksi atau lebih atau seorang saksi ahli untuk didengar keterangannya yang sebelumnya disumpah. Arbiter atau majelis arbitrase juga dapat meminta bantuan 
seorang atau lebih saksi ahli untuk memberikan keterangan tertulis mengenai suatu persoalan khusus yang berhubungan dengan pokok sengketa.

k) Putusan arbiter atau majelis arbitrase diambil berdasarkan ketentuan hukum atau berlandaskan keadilan dan kepatutan. Para pihak berhak menentukan pilihan hukum yang akan berlaku terhadap penyelesaian sengketa yang mungkin atau telah timbul antara para pihak. Putusan tersebut harus diucapkan dalam waktu paling lama 30 hari setelah pemeriksaan ditutup.

1) Putusan arbitrase bersifat final dan mempunyai kekuatan hukum yang ketat dan mengikat para pihak.

m) Selanjutnya putusan arbitrase tersebut didaftarkan oleh arbiter atau kuasanya kepada kepaniteraan pengadilan negeri setempat untuk dimintakan pengakuan dan eksekuatur

\section{Simpulan}

LAPSPI memiliki alur penyelesaian sengketa yaitu saat terjdi sengketa perbankan case manager LAPSPI menentuka terlebih dahulu apakah sengketa tersebut bisa diselesaikan melalui LAPSPI atau tidak. Kemudian jika bisa diselesaikan melalui LAPSPI selanjutnya akan dilihat apakah para pihak sebelumnya sudah memiliki prjanjian mengenai penelesaian sengketa atau tidak. Jika sudah ada perjanjian maka sengketa tersebut bisa langsung di proses penyelesaiannya melalui 3 (tiga) layanan LAPSPI yaitu mediasi, ajudikasi ataupun arbitrase. Namun jika belum ada maka harus terlebih dahulu diajukan ke bank yang bersangkutan untuk dimintai persetujuan apakah bank tersebut sepakat untuk menyelesaikan melalui LAPSPI atau tidak. Selanjutnya jika sepakat maka nasabah dan bank membuat acta compromise barulah setelah itu para pihak memiliih salah satu layanan LAPSPI.

\section{E. Saran}

LAPSPI seharusnya lebih meningkatkan lagi jumlah SDM seperti tenaga mediator, ajudikator dan arbiter sehingga tidak perlu memakai mediator, ajudikator dan arbiter dari lembaga lain. Selain itu tentunya LAPSPI lebih meningkatkan lagi sosialisai mengenai layanan yang diberikan LAPSPI terhadap masyarakat serta perbankan secara menyeluruh karna berdasarkan wawancara yang saya lakukan LAPSPI mengakui bahwa di anggotanya sendiri tidak semuanya mengetahui adanya LAPSPI hanya bagian - bagian tertentu dari perbankan yang mengetahui adanya LAPSPI apalagi masyarakat yang berada diluar Jakarta yang jauh dari kantor LAPSPI sehingga sosialisasi itu sangatlah penting agar seluruh masyarakat dapat mengetahui adanya lembaga alternatif penyelsaian sengketa di sektor perbankan.

\section{F. Daftar Pustaka}

\section{Buku}

Jimmy Joses Sembiring. 2011. Cara Menyelesaikan Sengketa di Luar Pengadilan; Negosiasi, Mediasi, Ajudikasi, \& Arbitrase. Jakarta: Visimedia.

Lawrence M Friedman (terjemahan M. Khozim). 2011. The Legal System: The Social Science Perspectif.terjemahan M. Khozim. Jakarta: Gramedia. 
Peter Mahmud Marzuki. 2014. Penelitian Hukum. Jakarta:Kencana Prenanda Media.

Sophar Maru Hutagalung,2014, Praktik Peradilan Perdata dan Alternatif Penyelesaian Sengketa .Jakarta: Sinar Grafika.

Soerjono Soekanto. 2010.Pengantar Penelitian Hukum. Jakarta:UI Press.

\section{Jurnal}

Abd. Aziz Billah. 2018. "Peran lembaga Alternatif Penyelesaian Sengketa Dalam Sektor Jasa Keuangan Guna Mendukung Pembangunan Ekonomi Nasional”., Jurnal Rechts Vinding Volume 7, Nomor 1. Jakarta: Fakutas Hukum Universitas Indonesia.

Agus Suwandono dan Deviana Yuanitassari. 2016. "Kedudukan Lembaga Alternatif Penyelesaian Sengketa Sektor Jasa Keuangan Dalam Hukum Perlindungan Konsumen”. Jurnal Bina Mulia Hukum, Volume 1, Nomor 1. Bandung: Fakultas Hukum Universitas Padjajaran.

Ema Rahmawati dan Rai Mantili, 2016, "Penyelesaian Sengketa Melalui Lembaga Alternatif Penyeleesasian Sengketa di Sektor Jasa Keuangan”, Jurnal Bina Mulia Hukum Volume 3 Nomor 2. Bandung: Fakultas Hukum Universitas Padjajaran.

Lukmanul Hakim, 2015, "Analisis Alternatif Penyelesaian Sengketa Antara Pihak Nasabah Dengan Industri Jasa Keuangan Pada Era Otoritas Jasa Keuangan (OJK)”, Jurnal Keadilan Progresif Volume 6. Nomor 2. Lampung: Fakultas Hukum Universitas Bandar Lampung.

Riska Fitriani, 2017,"Alternatif Penyelesaian Sengketa Melalui Mediasi Dalam Masyarakat Adat Melayu Riau”, Riau Law Journal Vol. 1 No.2. Pekanbaru: Fakultas Hukum Universitas Riau. 